\title{
Structure, Conduct and Performance of Timber Market in Ife East Local Government of Osun State, Nigeria
}

\author{
${ }^{* 1}$ BABATUNDE, TO; ${ }^{2}$ BABATUNDE, OO \\ ${ }^{*}$ Department of Forestry Technology, Federal College of Forestry, Jericho Ibadan Oyo State, Nigeria. \\ ${ }^{2}$ DepartmentofWood and Paper Technology, Federal of Forestry, Jericho, Ibadan, Oyo, Nigeria \\ *Corresponding Author Email:sollybee2012@gmail.com,Tel +2348033948859
}

\begin{abstract}
The study focused on the structure, conduct and performance of timber market in Ife-east Local Governments of Oyo state. The major objective of this study is to assess the marketing pattern of timber in the study areas. The research method used for achieving the general objectives involved Descriptive Statistics and Gini Coefficient. Variations were observed in the price of the timber of the same species but different size because price determination is based on bargaining power. The result showed majority of respondents $(58.8 \%)$ had secondary education, Muslim was dominant (54.6\%) in the timber marketing and majority of marketers had regular supply of their product. . Government policy, high cost of transportation, inadequate credit facilities and high cost of energy and power were some of the constraints faced by timber marketers in the study area. The use of modern equipment and machines are needed to replace the outdated equipment in order to increase the output and profit. The level of access to credit facilities should be improved upon by encouraging the respondent to form cooperative societies so that they can mobilize enough working capital for their business.
\end{abstract}

\section{DOI: https://dx.doi.org/10.4314/jasem.v24i6.23}

Copyright: Copyright (C 2020 Babatunde and Babatunde. This is an open access article distributed under the Creative Commons Attribution License (CCL), which permits unrestricted use, distribution, and reproduction in any medium, provided the original work is properly cited.

Dates: Received: 21 April 2020; Revised: 26 May 2020; Accepted: 20 June 2020

Keywords: Structure, conduct, Performance, Timber, ife, market

Nigeria forests are naturally endowed with plant and animal species (flora and fauna) and for this reason it has been protected for timber production. Timber can be described as wood in a form suitable for construction or carpentry, joinery or reconversion to manufacturing purpose. Timber has been used as a building material for over 400,000 years and it is very common and best known material for house construction including ramming of floors, walls and roofs. According to (Cumming et al., 2005) timber accounts for about half of worldwide wood consumption. Timber marketing is an asset in the economy of timber. According to (Lintu, 2005) marketing provides a means through which people can create efficient economic value for their resources and products. Consequently, efficiency in timber marketing is an economic asset to the forestry subsector for a sustained resource production, distribution and consumption. An efficient marketing system of timber will provide a means for maximizing products values and also stimulating equitable distribution of its economic benefits among the different actors in the market. (Agustion and Poopola, 2011). Sawmill is a critical industry whose performance not only has direct implementation for present livelihood but vast majority of the industries round wood produced in Nigeria. Most existing sawmill comprise old and poorly maintenance horizontal band saws that are manually pushed against stationary logs. This technology is outdated, it is unsuitable forte smaller $\operatorname{logs}$ available today, its lumber recovery is estimated at only $40-45 \%$, and it does not allow sawing for grade. For example, Nigeria's timber sector contributes a estimated US\$39 billion annual in foreign exchange by supplying wood fuel to meet $80 \%$ of the country's total energy needs (FAO, 2005) Market structure deals with how a market is organized. It defines the marketing system of different types of enterprises, their behavior and the relationship, as well as the relationship among various sellers and buyers, and between buyers and sellers. Market structure is therefore concerned with the organizational characteristics of a market, which influence the nature of competition and pricing with the market. It can further explain which segment of the market posses the largest share of the market or business. Concentration, which shows the nature of the market and the pricing system, is very important in market structure analysis (Okereke, 2011). From the foregoing, a good market structure influences the efficiency of a market. Thus, (Adeyeye and Dittoh, 2006) maintained that an efficient and good marketing system can only operate where there is good market structure and conduct in place and it is fully utilized. 
Consequently, market structure, conduct and performance are instrumental to the efficient market function which serves as a tool for distribution of products for economic development of a nation. According to (Crammer and Jensen, 2002) market structure is a description of the activities of buyers and sellers in the market. Market conducts deal with the behaviour that exits among buyers and sellers in the market. It is also a source of livelihood of many Nigeria.

\section{MATERIALS AND METHODS}

Area of study: The study was carried out in Ife East of Osun state, Nigeria. Ife East is a local government area in Osun state, with headquarters in OkeOgbo in Ile Ife. The local government area is in Osun East senatorial district. Ife East local government area also forms a federal constituency alongside Ife Central, Ife North and Ife South local government areas. Ife East local government area covers an area of $172 \mathrm{~km} 2$. The local government area is bounded to the north by Ife Central local government area, to the east by Atakumosa west local government area, to the south by Ife South local government area, and to the West by Ife north Local government area Latitudes $7^{\circ} 28^{\prime} \mathrm{N}$ and $7^{\circ} 45^{\prime} \mathrm{N}$ and longitudes $4^{\circ} 30^{\prime} \mathrm{E}$ and $4^{\circ} 34^{\prime} \mathrm{E}$. Ife East is a rural area with settlements where agriculture is occupied by most. Ife has an undulating terrain underlain by metamorphic rocks and characterized by two types of soils, deep clay soils on the upper slopes and sandy soils on the lower parts. Within the tropical savanna climate zone of West Africa, It has average rainfall of $1,000-1,250 \mathrm{~mm}$ (39-49 in) usually from March to October and a mean relative humidity of $75 \%$ to $100 \%$. Ife is east of the city of Ibadan and connected to it through the Ife-Ibadan highway; Ife is also $40 \mathrm{~km}$ (25 mi) from Osogbo and has road networks to other cities such as Ede, Ondo and Ilesha. There is the Opariver and reservoir, that serves as a water treatment facility for OAU College

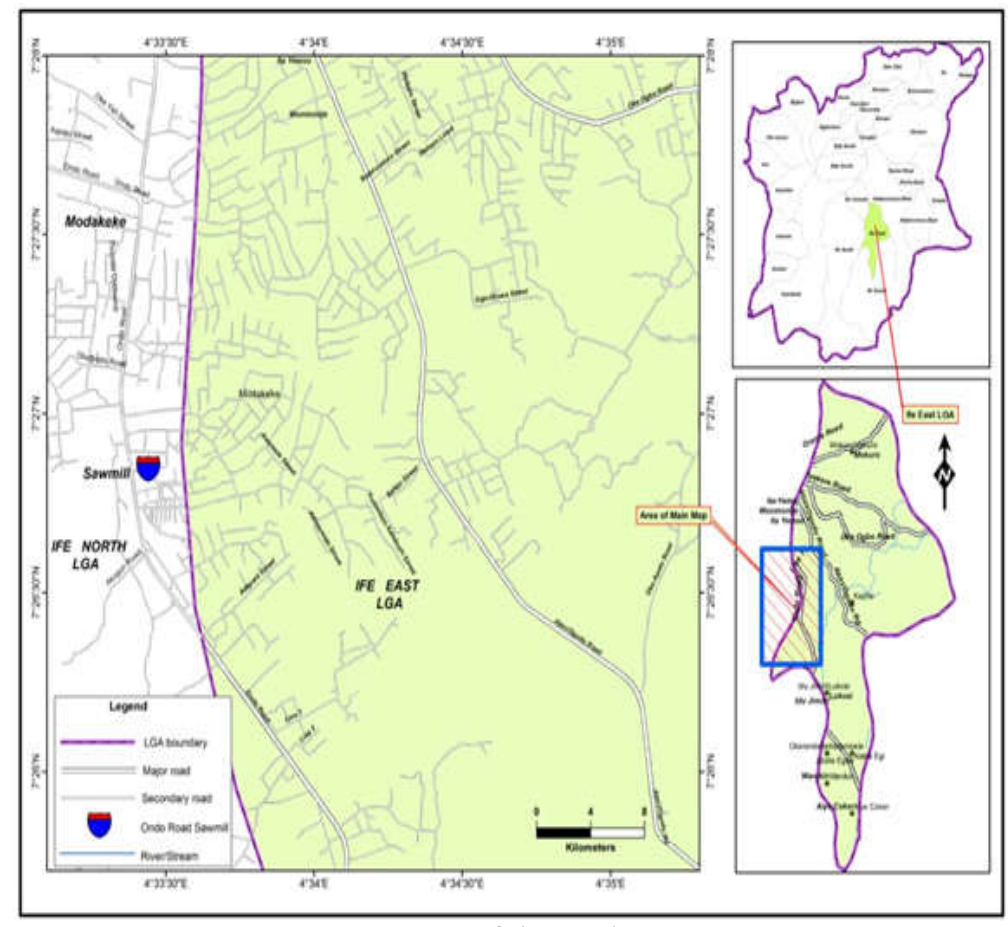

Fig 1 Map of the study area.

Sample technique: multistage sampling was used in this study. In the first stage, Ife east local government was purposively chosen. The reason being that it has the largest forest coverage area and housed the highest saw-mills and forest reserves in the area. Secondly, five saw-mills were randomly selected from the local government which are Arowo sawmill, Ifesowapo sawmill, Atagijere sawmills, Ajowa sawmill and Oluwatoyin sawmill. Thirdly, twenty (20) timber marketers were randomly selected from each sawmill. Altogether one hundred questionnaire were administered out of each ninety seven were retrieved. Data was collected with the administration of structured questionnaire. Secondary data was collected from publications and journals. The data was collected from 100 timber marketers in the Ife east local government area through personal interview.100 
questionnaires were administered out of which 97 were retrieved.

Method of data analysis: Data was analysed using Descriptive statistics Gini Coefficient. The computation of Gini Coefficient has the following relationship

$$
G C=1-\sum X Y
$$

Where $G C=$ Gini Coefficient; $X=\%$ of cattle sellers; $Y=$ Cumulative of income from sellers; $\Sigma$ $X Y=$ Summation of $X Y$

\section{RESULTS AND DISCUSSIONS}

Socio-economic characteristics of the respondent: Table 1 present the result of the socio demographic characteristics of the respondent. The result revealed that $44.3 \%$ are of age $40-49$ and $50-59$ respectively while $8.2 \%$ are of age 60 above and $3.1 \%$ are of age 30-49. The result showed that majority were adult. This result corroborate the findings of (Okumadewa et al., 2000, Babatunde, 2019) which stated that those in the age range of $40-50$ years of age were productive and have the power to produce work The result revealed that most of the timber marketers were male $(67 \%)$, which means majority of the respondent were male and they have more energy to carry out the task. This result is in agreement with (Olawumi and Okunlola, 2015, Babatunde et al., 2017) when they stated that majority of the respondent in Ondo sawmill were male and the result disagree with (Alfred and Akitade, 2002) when they opined that sawn wood marketing were dominated by female. The result further revealed that $60.8 \%$ were married while $16.5 \%$ were divorced, $15.5 \%$ were single and $7.2 \%$ were window and widower. Marital status determine the level of household size which by extension may indicate the available labour supply, family, income composition and savings pattern (Mafimimisebi et al.,2000) opined that marital status of a person determines the degree of responsibility of that person in the society and further submit that, marital status is very important as it helps to have an idea of a marketing participant's devotion to the marketing process and the likely outcome of this on his or her business activities. Marriage confers responsibility (Akinbile, 2007,Babatunde,2019) Furthermore 58.8\% of the respondent had secondary education, $27.8 \%$, $11.3 \%$ have primary and tertiary education respectively while $2.1 \%$ had no formal education. Formal education for most market stake holders confers a wide range of opportunities and advantages for success in life compared with illiteracy.(Babatunde,2019) Based on a prior, it is expected that higher levels of educational attainment by a markets dynamics and thus better profit from use of sound business principles and wise business decisions. Education enhances the efficiency of trade business (Oluyole and Usman, 2006). This study contradicts earlier study by (Alfred and Akinade, 2002) on wood marketing where majority of the sellers were illiterate

Table 1: socio economic characteristics of respondent in selected

\begin{tabular}{lll}
\multicolumn{3}{c}{ local government } \\
\hline Gender & Frequency & Percentage \\
\hline Male & 65 & 67 \\
Female & 32 & 33 \\
Total & $\mathbf{9 7}$ & 100 \\
\hline Age & 0 & \\
30 yrs & 03 & 0 \\
30-39yrs & 43 & 3.1 \\
40-49yrs & 43 & 44.3 \\
50-59yrs & 08 & $44 ; 3$ \\
60yrs above & $\mathbf{9 7}$ & 8.2 \\
Total & & $\mathbf{1 0 0}$ \\
\hline Marital Status & 22 & \\
Single & 59 & 22.7 \\
Married & 16 & 60.8 \\
Divorced & $\mathbf{9 7}$ & 16.5 \\
Total & $\mathbf{1 0 0}$ \\
\hline Education Background & \\
No formal education & 02 & 2.1 \\
Primary school & 27 & 27.8 \\
Secondary school & 57 & 58.8 \\
Tertiary education & 11 & 11.3 \\
Total & $\mathbf{9 7}$ & $\mathbf{1 0 0}$ \\
\hline Religion & & 45.4 \\
Christianity & 44 & 54.6 \\
Islam & 53 & $\mathbf{1 0 0}$ \\
Total & $\mathbf{9 7}$ & \\
\hline
\end{tabular}

Table 2 present of the distribution of respondent towards structure and conduct of timber market. .The results shows that $17.5 \%$ of the marketers were wholesalers while $20.6 \%$ were retailers and $61.9 \%$ operate both types of business. This result shows that the majority of the respondents were both retailers and wholesalers this show that the market nature is tending towards monopoly with majority combining both wholesale and retail business together. The results further show that $97.9 \%$ of the marketers had regular supply of timber while $2.1 \%$ of the industry had no regular supply of the products. This implies that the timber business is not a seasonal business.

About 53.6\% and 32\% transport their products by truck and lorry respectively, while $14.4 \%$ transported their products by car. The result shows that majority of the respondents transported their product by truck. This result is in agreement with Agbonlahor (2010) who found out that majority of small holder timber mills in Ogun state owned their trucks for transport purposes. The results again show that $9.2 \%$ had between 1-5years experience, 30.8\% had between610 years experience while $60 \%$ of timber had above 
10years experience. This result implies that many of the marketers have been in the timber market business for a long period of time which made them to be efficient in the marketing of timber.

Table2: Distribution of respondent towards Structure and Conduct of timber market

\begin{tabular}{|c|c|c|}
\hline Variable & Frequency & Percentage \\
\hline \multicolumn{3}{|c|}{ Ownership of Business } \\
\hline Retaliers & 20 & 20.6 \\
\hline Wholesalers & 17 & 17.5 \\
\hline Both & 60 & 61.9 \\
\hline Total & 97 & 100 \\
\hline \multicolumn{3}{|c|}{ Supply of product } \\
\hline Regular supply & 95 & 97.9 \\
\hline Not regular & 02 & 2.1 \\
\hline Total & 97 & 100 \\
\hline \multicolumn{3}{|c|}{ Means of transportation } \\
\hline Truck & 52 & 53.6 \\
\hline Lorry & 31 & 32 \\
\hline Car & 14 & 14.4 \\
\hline Total & 97 & 100 \\
\hline \multicolumn{3}{|c|}{ Years of Experience } \\
\hline $1-5$ years & 09 & 9.2 \\
\hline $6-10$ years & 30 & 30.8 \\
\hline Above 10 years & 58 & 60.0 \\
\hline Total & 97 & 100 \\
\hline \multicolumn{3}{|l|}{ No of Workers } \\
\hline $1-3$ workers & 20 & 20.6 \\
\hline $4-5$ workers & 27 & 27.8 \\
\hline Above6workers & 50 & 51.5 \\
\hline Total & 97 & 100 \\
\hline \multicolumn{3}{|c|}{ Membership of Association } \\
\hline Yes & 95 & 97.9 \\
\hline No & 02 & 2.1 \\
\hline Total & 97 & 100 \\
\hline
\end{tabular}

The results showed that $20.6 \%$ had between $1-3$ workers, $27.8 \%$ had $4-5$ workers while $51.5 \%$ had more than 6 workers in the timber business. This result implies that the majority of the industry had above 6 workers and this could contribute to the output of their production. The reveals the structure of the timber business, $97.9 \%$ of the respondents belong to association, while $2.1 \%$ of the respondent did not belong to any association. This means that before any of the timber marketers can operates in the market, he or she must belong to associations like sawyers associations, timber marketer association, sawmilling association and timber seller association. This result agreed with (Usman et al 2013) who stated that majority of the respondent in Ebute Metta belong to association. The structure of a market helps in price determination and price fixing of a products. i.e the marketers cannot sell their product anyhow because they belong to an association. This lead to high profit accruing to the stake holders in the market at the expense of buyers, who will find it difficult to haggle prices of these products. Therefore, the timber business or market in the study area is not determined and controlled by the forces of demand and supply which results into imperfect market structure since the timber sellers or marketers are the price marker signifying monopoly.

\begin{tabular}{lll} 
Table 3Distributionof respondents towards market performance \\
\hline Variables & Frequency & Percentage \\
\hline Business Ownership & & \\
Sole proprietorship & 52 & 53.6 \\
Partnership & 35 & 36.1 \\
Cooperative society & 10 & 10.3 \\
Cooporation & 97 & 100 \\
Total & & \\
Nature of Business & & \\
Ownership & & \\
Private & 97 & 100 \\
Public & 0 & 0 \\
Total & 97 & 100 \\
Business operation & & \\
capital & & \\
Less than 500,000 & 05 & 5.2 \\
N500,001- 1,000000 & 25 & 25.8 \\
A1,000001- 5,000000 & 50 & 51.5 \\
Above 5,000000 & 17 & 17,5 \\
Total & 97 & 100 \\
Annual income & & \\
Less than 5,000000 & 10 & 10.3 \\
N1,000000- 2,000000 & 42 & 43.3 \\
N2,000001- 3,000000 & 31 & 32 \\
N3,000001- 4000000 & 5 & 5.2 \\
Above 4000000 & 8 & 8.2 \\
Total & 97 & 100 \\
\hline
\end{tabular}

This is in contract to (Sambe et al., 2016) who stated that sawmill market structure in Benue tends towards olig. The table 3 revealed $53.6 \%$ were sole proprietor, $36,1 \%$ and $10.3 \%$ were partnership and cooperative society respectively. It revealed from the result that majority of the respondent were sole proprietor owner of the business in the study area. The result also reveal that $5.2 \%$ realized $\$ 3,000001-\$ 4,000000$ per annum, $8.2 \%$ realized above $\$ 4,000000$ per annum and $32 \%$ realized $\$ 2,000001-3000,000$ as annual income while $43.3 \%$ realised $\$ 1,000000$ - $\$ 2,000000$ This result implies that majority of respondent realized $\$ 1,000,000$ - 2,000000 as annual income.

The result agreed with (Babatunde,2018) who found that annual income earned by timber industry in Ijebu North Local Government was well above the Federal Government approved minimum wage According to the result there is enough profit from sales of timber product in the market. This implies that both young and old people could invest in timber business as a means of livelihood which points to the fact that this business could help raise the standard of living through reduction of poverty and unemployment in our society. This result show that the market performance of the nature of the business tends towards monopoly. The result also shows that $5.2 \%$ had access to less than $\mathrm{N} 500,000$ to start their business, $17.5 \%$ had access to above $\$ 5,000000$, and 
$43.3 \%$ had access to $\$ 1,000000-\$ 2,000000$. This implies that even though the timber business is capital intensive, anybody amount less than $\$ 500,000$ can invest on the business as a means of livelihood. This result is in agreement with (Akanni and Adetayo, 2011) which found out that amount of working capital for a business enterprise often determines the level of output and accruable profit margin.

Table 4 Structure and conduct of timber marketers in the study area:The market structure in the study area was determined by Gini coefficient. Gini coefficient was applied to measure the relative degree of income distribution among the timber sellers. The values of Gini coefficient greater than 0.3445 are high indicating inequitable distribution of income/sales (Dillion and Herdeker 1993). The Gini coefficients for timber marketer in the study area is 0.375 . This value indicate higher level of concentration and consequently high in efficiency in the market structure. This is in agreement with Mafimisebi et al., (2006) on the analysis of the fundamental in Palm oil marketing in Osun State, Nigeria which had Gini coefficient of 0.4680 , and also in agreement with the work of Afolabi (2006) on the assessment of palm oil marketing in Ondo State, Nigeria which got 0.4166 for Gini Coefficient. With these high levels of concentration, the market structure can be described as imperfect market which could be monopoly. In this market structure, the sellers determine the price rather than the forces of demand and supply and the outcomes will be bad performance as a result of control of certain stakeholders which are basically sellers in most cases, this result agreed with Usman et al., 2014

\begin{tabular}{|c|c|c|c|c|c|c|c|c|}
\hline $\begin{array}{l}\text { Income } \\
\text { sales }\end{array}$ & $\begin{array}{l}\text { Number } \\
\text { of sellers }\end{array}$ & $\begin{array}{l}\% \text { of } \\
\text { sellers } \\
(\%) \mathrm{X}\end{array}$ & $\begin{array}{l}\text { Cumulative } \\
\text { frequency }\end{array}$ & $\begin{array}{l}\text { Cumulative \% } \\
\text { Of sellers }\end{array}$ & Total sales & $\begin{array}{l}\% \text { of } \\
\text { total } \\
\text { sales }\end{array}$ & $\begin{array}{l}\text { Cumulative } \\
\% \text { of total } \\
\text { sale }(Y)\end{array}$ & $\mathrm{XY}$ \\
\hline $\begin{array}{l}50,000- \\
70,000\end{array}$ & 32 & 33 & 32 & 12.3 & 768000 & 26.2 & 26.2 & 0.08646 \\
\hline $\begin{array}{l}70,001- \\
100,000\end{array}$ & 22 & 22.7 & 54 & 20.8 & 829,000 & 28.2 & 54.4 & 0.123488 \\
\hline $\begin{array}{l}101,001- \\
130,000\end{array}$ & 23 & 23.7 & 77 & 29.6 & $1,008,000$ & 34.3 & 88.7 & 0.210219 \\
\hline $\begin{array}{l}131,001- \\
160000\end{array}$ & 20 & 20.6 & 97 & 37.3 & 332,000 & 11.3 & 100 & 0.206 \\
\hline Total & 97 & 100 & 260 & 100 & $2,937,000$ & 100 & & 0.626167 \\
\hline
\end{tabular}

\begin{tabular}{lll}
\multicolumn{4}{c}{ Table 5: Constraints Facing the Timber Business } \\
\hline Constraint & Frequency & \% \\
\hline Government Policy & 6 & 6.2 \\
Inadequate facilities in market & 5 & 5.2 \\
High cost of energy and power & 19 & 19.6 \\
Inadequate credit facilities & 18 & 18.6 \\
High transportation cost & 19 & 19.6 \\
Government policy and high transport cost & 16 & 16.5 \\
Inadequate credit facilities and high transport cost & 14 & 14.4 \\
\hline
\end{tabular}

Source: Field survey, 2019

Constraints facing the Timber Business in the Study Area: Table 5 shows that timber industry in Ife East Local Government encountered several constraints. About $19.6 \%$ of the timber industry had high cost of energy and power, $18.6 \%$ had inadequate credit facilities, $19.6 \% \%$ incurred high transportation cost while about $6.2 \%$ complained of unfavourable government policy about timber industry. The timber industry faced with high cost of energy and power as one of major constraint, this is due to the epileptic power supply and invariably high cost of procuring diesel and petrol to power their machine and also their access to credit facility was poor due to high interest rates charged by the commercial banks .High cost of transportation was also a major constraint resulting from bad road network in many rural areas and cities where they source their timbers and the available transport tend to exploit the respondents by charging exorbitant fare. This result corroborate the position of Akanni and Adetayo (2011) who observed that access to credit facilities and high cost of energy affected the sawmilling timber industries in Ijebu ode.

Conclusion: In the context of the results obtained from this study timber business are important sources of income to many households in Nigeria and the study area in particular. It is however experiencing major setbacks .For instance, problem of inadequate credit facilities may be addressed by coming together of the timber business men and women to form cooperative 
societies so that they can have access to sufficient credit facilities that could be mobilized for their business operations. Adequate investment should also be made in the energy and power sector so that the timber industry operators can profitably and sustainably keep on operating their business.

\section{REFRENCES}

Agbonlahor, MU (2010): Productivity dispersion and resources of Technical in efficiency in smallholder timbermills in Ogun state Nigeria. J. Hum. Soc. Sci. and Create. Arts. 49-60.

Agustion S, Popoola, L (2011): Nonwood forest products and services for socioeconomic development. A compendium for technical and professional forestry education. The African Forest Forum, Nairobi, Kenya. 2011; 219.6 .

Akanni. KA, Adetayo AO (2011): Estimation of cost return structure and technical efficiency in sawmilling industry in ijebudivision Ogun state, Nigeria. J. Fores. Res. Manage.8: 64-79

Akerele, EO (2013): Consumption, Savings and Investment pattern among rural farming household in Abeokuta north local government area Ogun state, Nigeria: J. Agric. Manage. Rural Develop. 4, 142.49.

Akinbile, CO, Fakayode, OA, Sanusi, KO (2011). Using Bamboo (Bambusa vulgaris) as field drainage material in Nigeria. Afr. J. Environ. Sci. Technol. 5(12): 1124-1127

Alfred, SDY; Akintade, SS., (2002): Factor influencing marketing and profitability of timber

Babatunde, TO (2019) Profitability and Value Addition Of Sawmills Industry InIjebu Division of Ogun State Nigeria. J. Res. Forestry, Wildlife. Environ. 11(2) 131140

Babatunde, TO; Babatunde, OO; Babatunde, KO; Aduloju, AR, Oluwalana, T; Inyang, V (2020) Profitability, Marketing Efficiency and Value Addition of Timber Industry in Ife East Local Government of Osun State, Nigeria. J. Appl. Sci. Environ. Manage. 24 (4) 589595 April 2020

Babatunde TO Babatunde OO Adejumo, AA; Okeleke SO (2017): cost and return structure sawmill industry in ijebu-ode, Ogun State. J. Res. Forest. Wildlife Environ. 9(3)

Crammer. G.L and Jensen, C.W (1982). Agricultural Economics and Agricultural Economics an Agricultural Business. $2^{\text {nd }}$ Edition. John Willey and Sons Inc.P.171.
Cunningham, PW, Cunningham MA, Saigo B (2005). Environmental science: A Global concern. $8^{\text {th }}$ edition, McGraw Hill600p

FAO, (2005). Microfinance and Forest-based SmallScale Enterprises, p. 246, FAO, Rome.

FAO. Food and Agricultural Organization (2010) Forest Resources Assessment; Global synthesis, FAO, Forestry paper $124 \mathrm{pp}$.

Lintu. L (2005): Marketing of non-wood forestproducts in developing countries. Tradeand Marketing of Forest Products. Unasylva. 183(46):4-12.5

Mafimisebi, TE. Awolola, DO, Fasasi, AR, (2006): Analysis of the Fundamental in Palm Oil Marketing in Osun State. Nigeria. Proceeding of $2^{\text {nd }}$ Annual Conference of School Agriculture and Agricultural Technology, Federal University of Technology, Akure, $24^{\text {th }}$ of May, 2006. Pp 192-196.

Okunmadewa FY., Mafimisebi, and TE, Adebayo SK (2000): Comparative Profitability of Wholesale and Retail Sun-Dried Meat Trade in Ibadan Metropolis. Journal of Technology and Education in Nigeria. Vol. 5 No. 1. Pp. 5-11.

Okereke O.(2011): the structural characteristics of the market grains in Eastern Nigeria

Oluyole, KA, Usman, JM (2006): Assessment of economics activities of cocoa licensed buying Agents (LBA) in Odeda Local Government Area of Ogun State. Akoka Journal of ol5 $130-140$.

Olawumi, AC; Okunola, G (2015): Development of the Nigerian Particle Board Industry. Ph.D. Thesis, Department of Forest Resources Management. University of Ibadan. 317pp

Sambe LN, Tee NT, DagbaBI (2016). Profitability Analysis of Timber Trade: "Potentials for Growth and Development of the Nigeria Sawmilling Industry." Nigeria Journal of Forestry. 23 (1): 85-90

Usman, JM, Adeoye, AS, Oke, OO ,Babatunde, TO (2014). Structure, Conduct and performance of timber marketing in EbuteMetta Area of Lagos State Proceedings of the $37^{\text {th }}$ Annual Conference of Forestry Association of Nigeria held in minna held in $9^{\text {th }}$ $14^{\text {th }}$ Noveember, 2014. 